\title{
Effect of Periodate on Competence in Bacillus subtilis
}

\author{
M. POLSINELLI AND S. BARLATI \\ Department of Genetics, University of Pavia, \\ Pavia, Italy
}

(Accepted for publication Io May 1967)

\begin{abstract}
SUMMARY
Treatment of competent cells of Bacillus subtilis with sodium periodate reduces markedly genetic transformation, at concentrations not significantly affecting cell viability. The action of periodate is not on DNA transforming activity. A reduction of transformation by this reagent is also obtained either if cells are treated before DNA addition or if they are first exposed to donor DNA for short time and then treated with periodate; if the cells have been pre-incubated with DNA for about $30 \mathrm{~min}$. the subsequent addition of $\mathrm{NaIO}_{4}$ is without effect. The action of periodate seems to be exerted on the adsorbtion and/or entry of DNA into the competent cells. The site of action of periodate is probably a component(s) of the cell wall involved in these processes.
\end{abstract}

\section{INTRODUCTION}

Bacterial cells which are susceptible to genetic transformation by DNA are said to be 'competent'. 'Competence' is a transitory state in the life cycle of the cell (Hotchkiss, 1954; Thomas, 1955) and different species of transformable bacteria require different growth conditions to reach this state. Conditions to render Bacillus subtilis cells competent were first worked out by Spizizen (1958); further studies were reported by Anagnostopoulos \& Spizizen (196I), Young \& Spizizen (196I), and by Nester (1964). Very little is known up to now about the biochemical and physiological events which determine the development of competence. The hypothesis that competence is determined by the synthesis of some enzyme or enzyme-like factor is supported by the findings of Pakula \& Walczak (I963) in Streptococcus; of Tomasz \& Hotchkiss (1964) in Pneumococcus, and of Charpak \& Dedonder (I965) in B. subtilis; these authors have reported that the supernatant of a competent culture can confer this property on non-competent cells; the active factor present in the supernatant is believed to be a heat labile protein. Studies by Young \& Spizizen (1963) in B. subtilis and by Ephrussi-Taylor \& Freed (1964) in Pneumococcus suggest that competence could be due to the synthesis of an autolytic enzyme which would act upon the cell wall, forming a partial protoplast.

Due to the central role attributed to the cell wall for the development of competence, we have undertaken a study of the effect of sodium periodate on competent cells, prompted by the observation of Sneath \& Lederberg (I96I) that this reagent alters the surface of male cells of Escherichia coli, thus inhibiting bacterial conjugation.

The present paper will report the effect of periodate on competence in Bacillus subtilis. A preliminary account of this work has been published elsewhere (Polsinelli \& Barlati, 1965). Inhibition of transformation in Haemophilus influenzae by periodate has been recently reported (Ranhand \& Lichstein, 1966). 


\section{METHODS}

Strains. The strains used are listed in Table I.

Table I. List of Bacillus subtilis strains used

\begin{tabular}{lcl} 
Strain & Genotype & \multicolumn{1}{c}{ Origin } \\
SB 25 & $h i s-2$ try-2 & J. Lederberg \\
SB 44 & try-2 & J. Lederberg \\
PB 3231 & prototroph str-r & $\begin{array}{l}\text { Derived from SB 25 in } \\
\text { our laboratory }\end{array}$
\end{tabular}

Symbols $:$ his $=$ histidine try $=$ tryptophan; $s t r-r=$ streptomycin resistance.

Media. For massive cultures Penassay broth (Antibiotic Medium No. 3, Difco) was used. For the transformation assays the medium was that described by Spizizen (1958), herein referred to as S medium; for all platings Davis \& Mingioli (I950) minimal medium (MM) was used.

DNA preparation. $400 \mathrm{ml}$. of culture of strain PB 323 I, grown overnight in Penassay broth at $37^{\circ}$ in an alternative shaker, were centrifuged; the cells washed twice with standard saline citrate (SSC: $0.15 \mathrm{M}$-sodium chloride and 0.015 sodium citrate), were resuspended in SSC (one fiftieth of the original volume) containing I mg. Bactolysozyme (Difco) $/ \mathrm{ml}$. and incubated at $37^{\circ}$; after 45 min., Duponol C (DuPont de Nemours, Wilmington, Del.) was added to a final concentration of I $\mathrm{mg} . / \mathrm{ml}$. and the incubation continued for another Io min.; then pronase (California Corp., Los Angeles, California), preincubated $\mathrm{I} \mathrm{hr}$ at $37^{\circ}$ in $\mathrm{H}_{2} \mathrm{O}$, was added to a final concentration of $\mathrm{I} \mathrm{mg.} / \mathrm{ml}$. and the lysate digested for another $4 \mathrm{hr}$ at $37^{\circ}$. The lysate was then shaken with an equal volume of chloroform containing $4 \%$ isoamyl alcohol for $20 \mathrm{~min}$., centrifuged Io min. at I0,000 r.p.m., and the supernatant precipitated with 4 volumes of ethanol; the nucleic acid fibres, collected with a stirring rod and washed in $70 \%$ ethanol, were then dissolved in $10 \mathrm{ml}$. SSC and incubated for $30 \mathrm{~min}$. at $37^{\circ}$ with $50 \mu \mathrm{g}$. pancreatic ribonuclease $/ \mathrm{ml}$. (Fluka, Buchs SG, Switzerland) and I unit ribonuclease $\mathrm{T}_{1}$ (Sankyo Co., Tokyo) $/ \mathrm{ml}$., both pre-heated for Io min. at $80^{\circ}$ in $\mathrm{H}_{2} \mathrm{O}$. The solution was then shaken once more with chloroform-isoamyl alcohol, centrifuged and the DNA was precipitated by adding to the supernatant $\mathrm{I} / \mathrm{I} O \mathrm{o}$ volume of acetate-EDTA (3 M-sodium acetate plus $0.00 \mathrm{I}$ M-EDTA, $\mathrm{pH} 7$ ) and 0.54 volume of cold isopropyl alcohol (Marmur, 1961). The precipitated DNA was dissolved in $5 \mathrm{ml}$. SSC and the concentration was determined by the diphenylamine method (Dische, 1955) using deoxyadenosin-monophosphate as standard. RNA was determined by the orcinol method (Ashwell, 1957) using adenosin-monophosphate as standard.

For the preparation of ${ }^{32} \mathrm{P}$-labelled DNA a $10 \mathrm{ml}$. culture of strain PB 323I, grown for $8 \mathrm{hr}$ in MM medium supplemented with $0 . \mathrm{I} \%$ Bacto-gelatin (Difco) was centrifuged and resuspended in the same volume of saline; $5 \mathrm{ml}$. of this suspension were added to $1000 \mathrm{ml}$. MM medium containing only I $4 \mathrm{mg}$. $\mathrm{KH}_{2} \mathrm{PO}_{4}$ and $4 \mathrm{mg}$. $\mathrm{K}_{2} \mathrm{HPO}_{4}$, added with I mg. Bacto-gelatin and $5 \mathrm{mc}$ carrier-free ${ }^{32} \mathrm{P}$, as sodium phosphate (Sorin, Saluggia, Italy). After $15 \mathrm{hr}$ of incubation at $37^{\circ}$ in an alternative shaker the cells were used for DNA extraction following the procedure above described. The preparations of ${ }^{32} \mathrm{P}$-labelled DNA used had a specific activity ranging from $8 \times 10^{4}$ to 
${ }_{10}^{5}$ per $\mu \mathrm{g}$. and contained less than $5 \%$ RNA. Radioactivity of DNA was determined in a Packard Tri-carb scintillation Spectrometer.

Transformation techniques. Competent cells were prepared by the method described by Young \& Spizizen (196I), slightly modified. Incubation with DNA was performed at $34^{\circ}$. A concentration of $2 \mu \mathrm{g} . / \mathrm{ml}$. of donor DNA was used, unless otherwise stated. Exposure to DNA was stopped by adding final concentrations of $20 \mu \mathrm{g}$. deoxyribonuclease (Worthington Biochemical Corp., Freehold, N.J.)/ml. and $\mathrm{IO}^{-3}$ M-magnesium chloride and the colonies transformed to tryptophan independence were scored following selection on MM medium supplemented with $20 \mu \mathrm{g}$. histidine $/ \mathrm{ml}$. Appropriate controls for backmutation were always run.

Periodate treatment. Competent cells to be treated with sodium periodate were centrifuged at $5000 \mathrm{rev} / \mathrm{min}$. for Io $\mathrm{min}$. at room temperature, washed once with same volume of the salt solution of Spizizen's medium lacking sodium citrate and resuspended in saline, at a concentration of approximately $10^{9} \mathrm{cells} / \mathrm{ml}$. Unless otherwise stated, to one volume of cell suspension, four volumes of fresh solution of sodium periodate of different concentrations were added and the mixture incubated for 10 min. at $37^{\circ}$ with agitation. The action of periodate was arrested by adding glucose to a final concentration of $1 \%(w / v)$; the suspension was centrifuged as above and the cells resuspended in $\mathrm{S}$ medium (about $5 \times 10^{8}$ cells per $\mathrm{ml}$.) were finally tested for transformation.

${ }^{32} \mathrm{P}$-DNA uptake. Competetent cells were exposed to ${ }^{32} \mathrm{P}-\mathrm{DNA}\left(\mathrm{O} \cdot \mathrm{I} \mu \mathrm{g} . / \mathrm{ml}\right.$.) at $34^{\circ}$ for different times; the reaction was arrested by addition of deoxyribonuclease (DNAse) and magnesium chloride, followed by incubation for $5 \mathrm{~min}$. at $37^{\circ}$. The cultures were then diluted three-fold with $\mathrm{S}$ medium, centrifuged and resuspended in the same medium; a portion was used for transformation tests and the remainder was filtered through a membrane filter (Millipore Corp., Malakoff, France), washed 5 times with Io $\mathrm{ml}$. samples of $S$ medium, and counted for radioactivity.

\section{RESULTS}

\section{Effect of periodate on viability and transformation}

Strain SB 25 competent cells were treated for $10 \mathrm{~min}$. with different concentrations of sodium periodate, according to the procedure described in Methods and incubated immediately afterwards with $2 \mu \mathrm{g} . / \mathrm{ml}$. of strain PB 323 I DNA for $30 \mathrm{~min}$. The treated cells were then tested for transformation to tryptophan independence and for survival. Figure $\mathrm{I}$ shows that both viability and transformation were reduced by increasing concentrations of periodate. However, periodate concentrations up to $5 \times \mathrm{IO}^{-4} \mathrm{M}$ had no significant effect on the viability, while markedly reducing transformation.

\section{Action of periodate on DNA transforming activity}

The effect of periodate could be ascribed either to action on the cells or to a direct damage on DNA; to choose between these possibilities two experiments were carried out.

DNA was dissolved in saline at a concentration of $20 \mu \mathrm{g} . / \mathrm{ml}$. and incubated for Io min. at $37^{\circ}$ with different concentrations of periodate; addition of glucose, to a final concentration of $\mathrm{I} \%$, stopped the action of the reagent. A fraction $0.1 \mathrm{ml}$. of this solution was tested for transforming activity. Table 2 shows that periodate did 
not appreciably affect the biological activity of DNA, thus ruling out the second possibility. To check whether the effect was not due to the production of some other toxic substance through the interaction of periodate with cells and glucose, in another experiment, to I ml. of a culture of competent cells treated with $5 \times 10^{-4} \mathrm{M}$-periodate, $2 \mu \mathrm{g}$. DNA $/ \mathrm{ml}$. and an equal amount of untreated competent cells were added. After $30 \mathrm{~min}$. of incubation at $34^{\circ}$, samples were plated to measure the frequency of transformation for tryptophan prototrophy. Results reported in Table 3 show that the transforming activity of DNA in those conditions was not affected.

Table 2. Transforming activity of DNA after treatment with different concentrations of periodate for to min. at $37^{\circ}$

\begin{tabular}{|c|c|}
\hline $\begin{array}{c}\mathrm{NaIO}_{4} \\
\text { concentration }\end{array}$ & $\begin{array}{l}\text { Transformation } \\
\text { frequency to } \\
\text { tryptophan } \\
\text { prototrophy* }\end{array}$ \\
\hline No periodate & $\mathrm{I} \cdot 2 \times 10^{-3}$ \\
\hline $0.05 \times 10^{-3} \mathrm{M}$ & $I \cdot I \times 10^{-3}$ \\
\hline $0.10 \times 10^{-3} \mathrm{M}$ & $1 \cdot 4 \times 10^{-3}$ \\
\hline $1.00 \times 10^{-3} \mathrm{M}$ & $1 \cdot 1 \times 10^{-3}$ \\
\hline
\end{tabular}

Table 3. Biological activity of DNA incubated with competent cells treated with $5 \times 10^{-4} \mathrm{M}$-periodate for $10 \mathrm{~min}$.

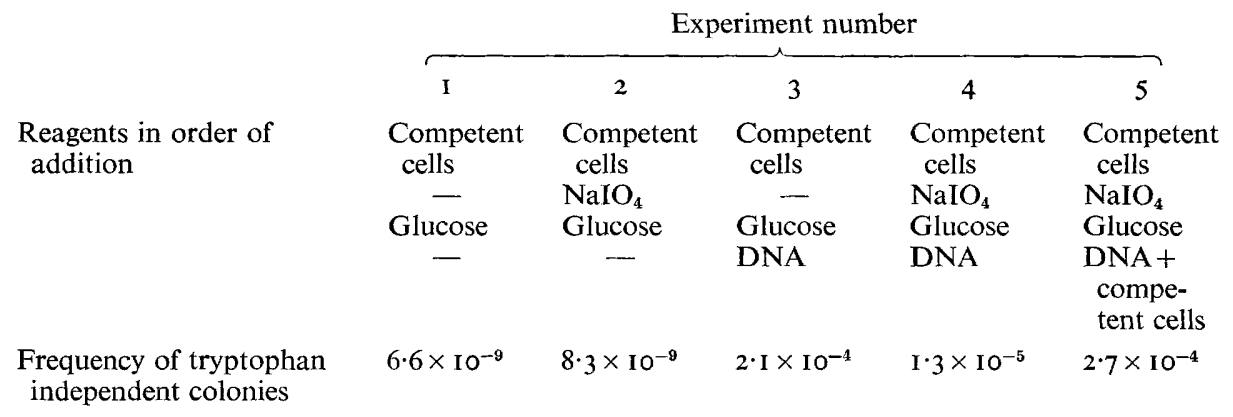

Exposure of competent cells first to DNA and then to periodate

The two experiments described above demonstrate that the phenomenon under study must be due to the reaction of periodate with the cells; such action can be exerted either on the process of binding and incorporation of DNA into the cells, or on the subsequent intracellular events leading to the integration of the marker in the recipient DNA. It is also possible that the effects on cells could be due to inactivation of one or more nuclei in multinucleate cells, so that there could be a decrease of transformability but not of the viability at low concentrations of periodate. If the action is in the process of binding and incorporation of DNA there is a way to decide between this and the other two explanations. Since $\mathrm{i}^{+}$has been shown that, before entering into the competent cell, the DNA bound to its surface remains sensitive to deoxyribonuclease (Lerman \& Tolmach, 1957; Levine \& Strauss, I965), the following experiments were performed in order to determine whether periodate acts in this extracellular stage, rather than in the following intracellular one. 
To a series of $250 \mathrm{ml}$. flasks containing $10 \mathrm{ml}$. of ice-cold competent cells, DNA was added to a final concentration of $2 \mu \mathrm{g} . / \mathrm{ml}$. and the flasks incubated at $34^{\circ}$. At different time intervals the content of each flask was poured in 3 volumes of icecold $\mathrm{S}$ medium, filtered through a Millipore membrane and washed 5 times with I $\mathrm{ml}$. of $\mathrm{S}$ medium salts lacking sodium citrate. In the case that we call 'zero time' ice-cold cells were diluted and washed immediately after the DNA addition. Cells were then resuspended from the filter membrane with I ml. of saline and $0.3 \mathrm{ml}$. samples were distributed into three test tubes; to one tube $0.7 \mathrm{ml}$. of $2 \times 10^{-4}$ M-periodate was added; to another one $0.7 \mathrm{ml}$. of deoxyribonuclease solution; to the third one $0.7 \mathrm{ml}$. of water. After $10 \mathrm{~min}$. of incubation at $37^{\circ}, 2 \mathrm{ml}$. of S medium containing $\mathrm{r} \%$ glucose were added and the cells were tested for transformation. The

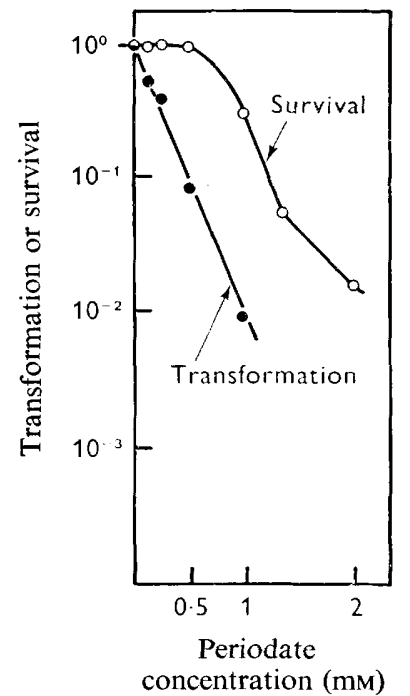

Fig. I

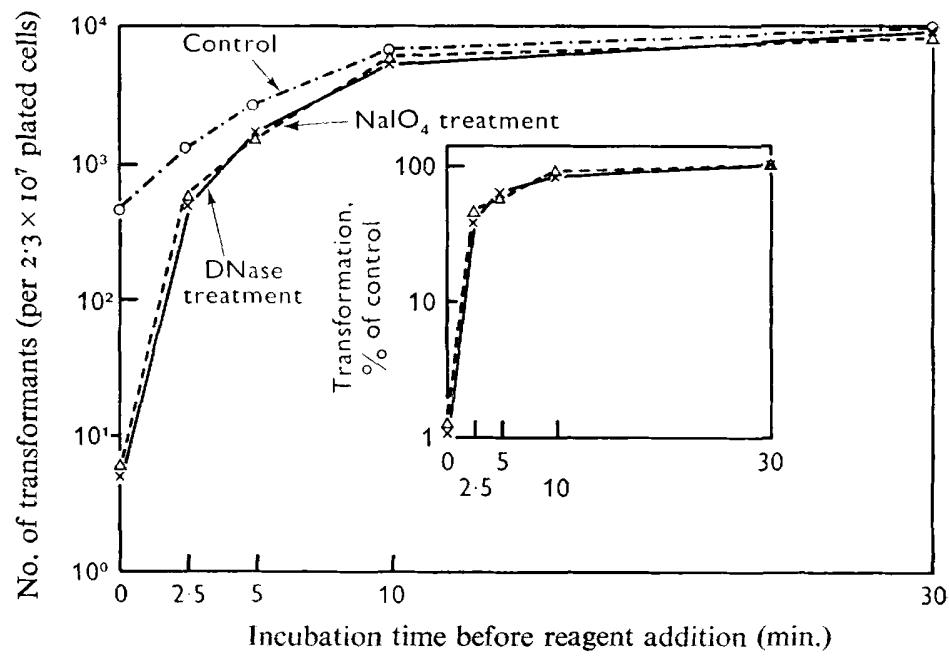

Fig. 2

Fig. I. Survival and transformation of competent cells incubated at $37^{\circ}$ for $10 \mathrm{~min}$. with different concentrations of sodium periodate. Transformation frequency in the cells not exposed to periodate was $0.6 \times 1 \mathrm{IO}^{-3}$.

Fig. 2. Transformation in cell cultures of SB 25 exposed to DNA $(2 \mu \mathrm{g} . / \mathrm{ml}$.) for different times and then treated with deoxyribonuclease or periodate or water. The insert reports the same values as percent of the control.

data are reported in Fig. 2. The curve indicated as 'control' refers to transformation obtained with cells which were exposed only to DNA and the water. The transformation data from cultures which, after DNA incubation, were also treated with periodate or DNase are reported in the other two curves. The graph shows that the cultures incubated with DNA for $30 \mathrm{~min}$. before adding periodate or DNAse or water gave similar amount of transformation. On the other hand, transformation obtained in tubes which were treated with periodate or with DNAse after a short time of incubation with DNA, was strongly reduced as compared to the transformation in the untreated tubes. Periodate seems therefore to act on the same stage in which DNAse acts. At 'zero time' the control tube shows appreciable transformation; this 
is due to the rapid attachment of DNA to the cell that must be so strong as to be insensitive to immediate dilution.

\section{Reduction of DNA uptake by periodate}

Experiments were performed in order to test directly if the reduction of transformation by periodate could be attributed to reduction of DNA uptake by the competent cell. Incorporation of DNA into the cells was followed on strains SB 25 and SB 44, the latter, a non-transformable strain, serving as a control for a specific incorporation by non-competent cells. Five hundred $\mathrm{ml}$. of cell culture of each strain

Table 4. ${ }^{32} P-D N A$ uptake and transformation in the competent strain SB 25. Cells not submitted $(a)$ or submitted $(b)$ to periodate action

(a)

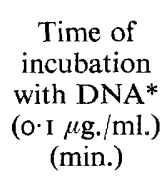

0
5
15
30

Cells not treated with periodate

No.
$\begin{gathered}\text { 32P-DNA } \\ \text { (c.p.m./ }\end{gathered}$
$\begin{gathered}\text { transformants } \\ \text { (per } 5.7 \times 10^{7}\end{gathered}$
$5.7 \times 10^{9}$ cells)

$\begin{array}{rc}86 & <\mathrm{I} \times 10^{-8} \\ 653 & \mathrm{I} 2 \mathrm{I} 5 \\ 1570 & 3025 \\ 2953 & 5302\end{array}$

(b) Cells treated with

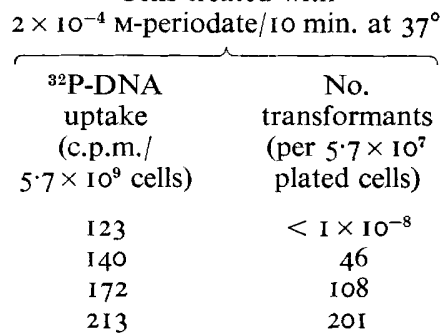

* Specific activity of DNA: $10^{5}$ c.p.m. $/ \mu \mathrm{g}$.

Table 5. ${ }^{32} P-D N A$ uptake and transformation in the non-competent strain SB 44. Cells not submitted $(a)$ or submitted $(b)$ to periodate action

(b)

(a) Cells not treated with periodate

Time of
incubation
with DNA*
(o. I $\mu \mathrm{g} . / \mathrm{ml}$.
(min.)

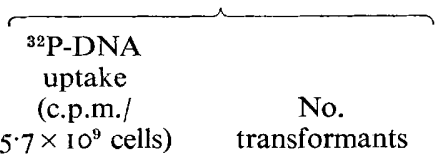

0
5
15
30

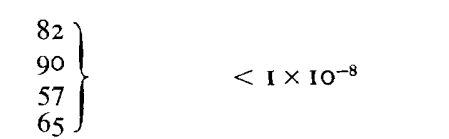

Cells treated with

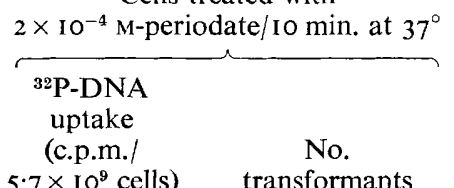
$5.7 \times 10^{9}$ cells) transformants

* Specific activity of DNA: $10^{5}$ c.p.m. $/ \mu \mathrm{g}$.

were centrifuged, washed with $S$ medium lacking sodium citrate, resuspended in $8 \mathrm{ml}$. of saline and divided in two portions; to one portion $12 \mathrm{ml}$. of $2 \times 10^{-4}$ M-periodate were added, to the other $12 \mathrm{ml}$. of water. After $10 \mathrm{~min}$. at $37^{\circ}$, the cells of each portion were resuspended in $40 \mathrm{ml}$. of transformation medium, distributed in four $100 \mathrm{ml}$. flasks ( $10 \mathrm{ml}$. per flask), and incubated with $0 \cdot 1 \mu \mathrm{g}$. ${ }^{32} \mathrm{P}-\mathrm{DNA} / \mathrm{ml}$. After different time intervals the cultures were treated with DNAse, tested for transformation and counted for radioactivity as described in Methods. In the 'zero time' flask the ro ml. culture was first diluted three fold with $\mathrm{S}$ medium and then treated with DNA 
preincubated with DNase for $5 \mathrm{~min}$. at $37^{\circ}$. The data are reported in Tables 4 and 5 . The experiments with the competent strain SB 25 shows: $(a)$ that both DNA uptake and number of transformants increase with the incubation time; $(b)$ that the uptake of DNA and the transformation are both significantly reduced in the cells treated with periodate as compared to the untreated ones. On the other hand, the noncompetent strain SB 44 gave no detectable transformation, as expected, and a low DNA uptake, which remained roughly constant during the incubation time. No significant differences in the uptake were also found in this strain between cells treated and not treated with periodate. On the assumption that also the cells of the competent strain can take up a similar fraction of DNA by some specific mechanism

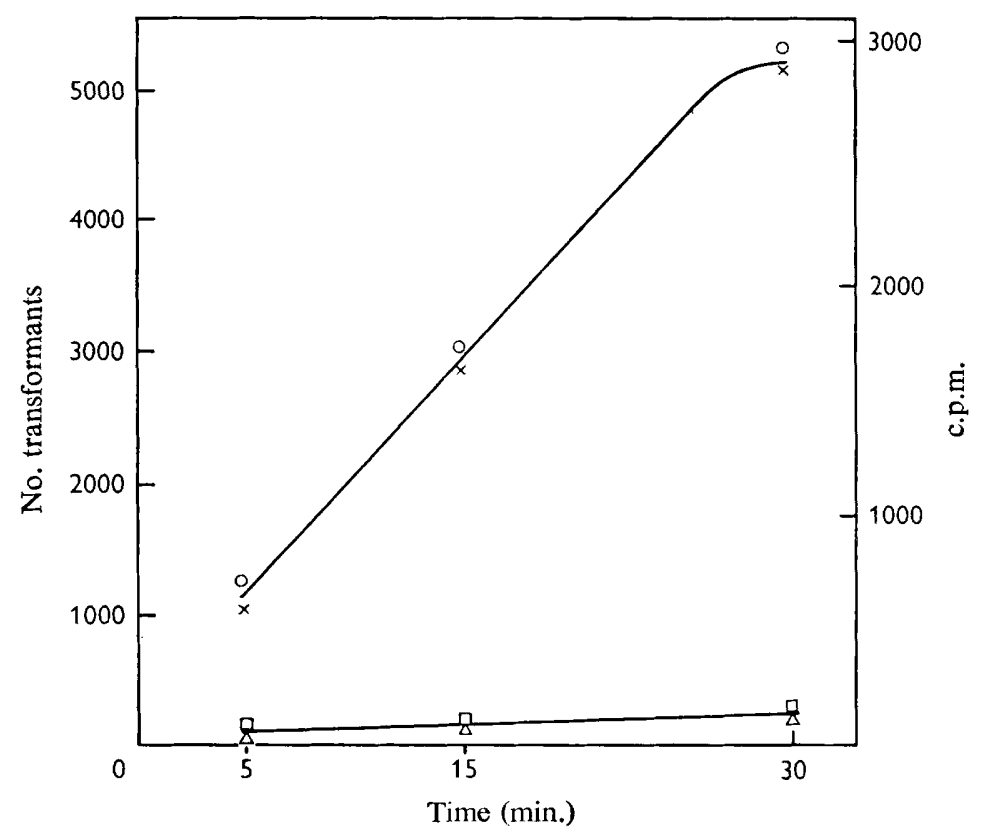

Fig. 3. DNA uptake and transformation in competent cells of SB 25 treated or not treated with periodate before the exposure to donor DNA. Data plotted have been corrected for the uptake found in non competent cells of SB 44. Transformation $(\mathrm{O}-\mathrm{O})$ and radioactivity $(x-x)$ in cells not treated with periodate. Transformation $(\triangle-\triangle)$ and radioactivity $(\square-\square)$ in cells treated with periodate.

not involved in the transformation process, the counts found in the non-competent cells have been subtracted from those found in the competent ones; the data so elaborated are plotted in Fig. 3. In the same figure also the transformation data have been reported, and the scales on the ordinate have been arbitrarily set at a ratio that underlines the striking parallelism between the two phenomena.

\section{DISCUSSION}

The results reported above show that treatment with periodate reduces the transformation of competent cells of Bacillus subtilis at concentrations not appreciably affecting cell viability. While the dependence of inactivation of transformation on 
periodate concentration indicated a 'single hit' process, cellular death appeared to be caused by a more complex mechanism. The possibility that periodate could affect transformation by acting in some way on transforming DNA was ruled out by the experiments in Table 2. The possibility that the donor DNA could be affected by some compound formed during cell periodate treatment, and still present in cell culture incubated with DNA, was also eliminated by the data in Table 3. It is also unlikely that, once the donor DNA has entered the competent cell, periodate may affect the transformation process, since competent cells first exposed to DNA for $30 \mathrm{~min}$. and then treated with periodate were transformed as well as the controls (Fig. 2). This experiment suggests also that the effect of periodate may be due to an alteration of some factor(s) involved in the maintenance of competence and not to a generalized damage on the cells; otherwise, one would expect reduction of transformation also in cells treated with periodate after $30 \mathrm{~min}$. of DNA incubation. On the other hand, for shorter incubations, periodate affected the transformation in a way analogous to DNase. The reduction by DNase, as mentioned above, is due to the fact that DNA, after binding to the competent cells, is still sensitive for a certain length of time to the enzyme (Lerman \& Tolmach, 1957; Fox \& Hotchkiss, I960; Levine \& Strauss, 1965). The reduction determined by periodate could therefore be attributed either to its interference in the process of entering of the DNA already bound to the cell or to the destruction of the receptor to which it is bound.

The hypothesis that periodate inhibits transformation by reducing DNA incorporation into competent cells is supported by the data in Table 4, which show that both DNA uptake and transformation were significantly reduced by periodate treatment. A certain amount of radioactivity was also incorporated by non-competent cells (Table 5) in absence of transformation, as already observed in B. subtilis by Young \& Spizizen (1963). Such radioactivity did not increase with time of exposure to DNA and was not reduced when cells were treated with periodate. The data plotted in Fig. 3, which have been corrected for the aspecific uptake found in the non-competent strain, show a good parallelism between the time dependence of DNA incorporation and transformation; this parallelism is even more marked if one observes the effect of periodate on the two phenomena, that seem to be affected in a similar way. The experiment demonstrates therefore that the treatment with periodate reduces the ability of the cell to take DNA up, and that the uptake so determined is a good measure of - or at least parallel with - the process leading to bacterial transformation, in agreement with the results of Lerman \& Tolmach (1957), Goodgal \& Herriott (1957), Fox (1957), Young \& Spizizen (196I and 1963). The site of action of periodate is probably a component(s) of the cell wall, involved in the binding and/or in the permeation of transforming DNA.

The Authors thank Professor L. L. Cavalli-Sforza for his useful advice and Miss Elena Negri for her technical assistance. This investigation was supported by a grant from Consiglio Nazionale delle Ricerche. 


\section{REFERENCES}

Anagnostopoulos, C. \& Spizizen, J. ( I96I). Requirements for transformation in Bacillus subtilis. J. Bact. 81, 741 .

Ashwell, G. (1957). Colorimetric analysis of sugars. Meth. Enzymol. 3, 73.

Charpak, M. \& Dedonder, R. (1965). Production d'un 'facteur de compétence' soluble par Bacillus subtilis Marburg ind- ${ }_{168}$. C. r. Séanc. Acad. Sci. 260, 5638.

Davis, B. D. \& Mingioli, E. S. (1950). Mutants of Escherichia coli requiring methionine or vitamin B I2. J. Bact. 6o, 17.

Dische, Z. (1955). Color reactions of nucleic acid components. In The Nucleic Acids. Ed. by E. Chargaff and J. N. Davidson, vol. 1, p. 285. New York: Academic Press.

Ephrussi-TAYlor, H. \& Freed, B. A. (1964). Incorporation of thymidine and amino acids into deoxyribonucleic acid and acid insoluble cell structures in pneumococcal cultures synchronized for competence to transform. J. Bact. 87, I $2 \mathrm{I}$ I.

Fox, M. (1957). Deoxyribonucleic acid incorporation by transformed bacteria. Biochim. biophys. Acta 26, 83 .

Fox, M. \& Hotchkiss, R. D. (1960). Fate of transforming deoxyribonucleate following fixation by transformable bacteria. Nature, Lond. $187,1002$.

Goodgal, S. H. \& Herriott, R. M. (1957). Studies on transformation of Hemophilus influenzae. In The Chemical Basis of Heredity. Ed. by W. D. McElroy and B. Glass, p. 336. Baltimore: The John Hopkins Press.

Hotchkiss, R. D. (1954). Cyclical behaviour in pneumococcal growth and transformability occasioned by environmental changes. Proc. natn. Acad. Sci., U.S.A. 40, 49.

Lerman, L. S. \& Tolmach, L. J. (1957). Genetic transformation. I. Cellular incorporation of DNA accompanying transformation in Pneumococcus. Biochim. biophys. Acta 26, 68 .

Levine, J. S. \& Strauss, N. (I965). Lag period characterizing the entry of transforming deoxyribonucleic acid into Bacillus subtilis. J. Bact. 89, $28 \mathrm{I}$.

Marmur, E. W. (I96I). A procedure for the isolation of deoxyribonucleic acid. J. molec. Biol. $3,208$.

Nester, E. W. (1964). Penicillin resistance of competent cells in deoxyribonucleic acid transformation of Bacillus subtilis. J, Bact. 87,867.

PAKULA, R. \& WALCZAK, W. (1963). On the nature of competence of transformable streptococci. J. gen. Microbiol. 31, 125 .

Polsinelli, M. \& Barlati, S. (1965). Inhibition by periodate of transformation in B. subtilis. Microbial Genet. Bul. 23, 22.

Ranhand, J. M. \& Lichstein, H. C. (1966). Periodate inhibition of transformation and competence development in Haemophilus influenzae. J. Bact. 92, 956.

SNeath, P. H. \& Lederberg, J. (196I). Inhibition by periodate of mating in Escherichia coli $\mathrm{K}$ I 2. Proc. natn. Acad. Sci., U.S.A. 47, 86.

SpIzizen, J. (1958). Transformation of biochemically deficient strains of Bacillus subtilis by deoxyribonucleate. Proc. natn. Acad. Sci., U.S.A. 44, 1072.

Thomas, R. (1955). Recherches sur la cinétique des transformations bactériennes. Biochim. biophys. Acta $19,467$.

Tomasz, A. \& Hotchisiss, R. D. (1964). Regulation of the transformability of pneumococcal cultures by macromolecular cell products. Proc. natn. Acad. Sci., U.S.A. 51, 480.

Young, F. E. \& SpIzizen, J. (I96I). Requirements for transformation in Bacillus subtilis. J. Bact. 81,823 .

Young, F. E. \& SpIzizen, J. (I963). Biochemical aspects in competence in the Bacillus subtilis transformation system. II. Autolytic enzyme activity of cell walls. J. biol. Chem. 238, 3I 26. 